\title{
SEMI-SYNTHESIS OF A23187 (CALCIMYCIN) ANALOGS \\ III. MODIFICATION OF BENZOXAZOLE RING SUBSTITUENTS, IONOPHOROUS PROPERTIES IN AN ORGANIC PHASE
}

\author{
M. Prudhomme, G. Dauphin and G. Jeminet \\ Université de Clermont II-Laboratoire de Chimie Organique Biologique, \\ (U.A. 04485 du C.N.R.S.), B.P. 45-63170 Aubière, France
}

(Received for publication December 23, 1985)

\begin{abstract}
Ten semi-synthetic analogs of A23187 (calcimycin), with only the benzoxazole ring substituents modified together with the ionophore X14885A were studied with regard to their calcium and magnesium carrier properties through an organic phase (toluene - butanol, $70: 30$ ). The results indicate that the carboxylic group and the oxazolic nitrogen, maintained in the ortho position are essential for the ionophorous properties. Further, the introduction of a substituent in place of the $\mathrm{NHCH}_{3}$ group, producing steric hindrance of the carboxylic group leads to a destabilization of the $2: 1$ associations with cations.
\end{abstract}

A23187 (calcimycin, 1) is an antibiotic isolated from a strain of Streptomyces chartreusis (NRRL 3882) $)^{1)}$ and belongs to the important family of carboxylic polyether ionophores ${ }^{2)}$. Its structure has been shown to be specifically suited to the transport of alkaline-earth cations through membrane phases via $2: 1$ neutral complexes ${ }^{3)}$. Since its discovery, this ionophore has been widely used as a tool for investigating the role of calcium in biological systems ${ }^{4}$, and more recently for synergistic effects with active compounds such as phorbol esters ${ }^{5}$.

$\mathrm{X}$-Ray crystallographic studies of the calcium ${ }^{6)}$ and magnesium ${ }^{7)}$ salts revealed that the 2-carboxy$3-N$-methylaminobenzoxazole ring is the main cation binding site in the (A23187) $)_{2}: \mathrm{M}^{++}$complexes (Fig. 1). In addition to ionic charge neutralization, one oxygen of the carboxylic group and the pyridine-like nitrogen of the oxazole ring are involved in ligand formation with the divalent cation.

In order to determine the respective roles of the substituents fixed on the benzoxazole moiety, we carried out chemical modifications to the naturally-occurring structure. From a selectively cleaved calcimycin, we have worked out a semi-synthetic approach in several steps which provides analogs with the correct overall stereochemistry ${ }^{8,9)}$. In this paper, the work is completed by the synthesis of two new compounds 6 and 7 bearing a methyl and a hydroxyl group respectively in place of the 3- $N$-methylamino group. In addition, we report the preparation of derivatives $9,10,11$ obtained from calcimycin by chemical modifications of the $N$-methyl group.

The set of compounds 1 $\mathbf{1 1}$ made available in this way have provided us with an insight into the divalent cation carrier properties of suitably designed structures. We have included in our study the divalent ionophore X14885A (12) recently isolated by WESTLEY et al. ${ }^{10)}$. All the structures investigated are shown in Table 1.

\section{Chemistry}

Synthesis of Compounds 6 and 7

These two analogs were obtained by the reactions described in Scheme 1.

The degradation of $\mathbf{1}$ to the carboxylic acid $\mathbf{2 1}$ has already been described ${ }^{8)}$ and will not be further 
Fig. 1. Calcium and magnesium coordination sphere in the (A23187) $)_{2} \mathrm{M}^{++}$complexes, following Alleaume and BarRans representation ${ }^{7}$.

The oxygen and nitrogen coordinating atoms are represented by $O$; for $>C(20)=0$, $\bullet$; for $>\mathrm{C}(1)-\mathrm{O}^{-}$of the carboxylate, $\$$; for the oxazolic nitrogen, repeated twice in the dimeric association of $\mathrm{A}$ and $\mathrm{A}^{\prime}$ molecules.

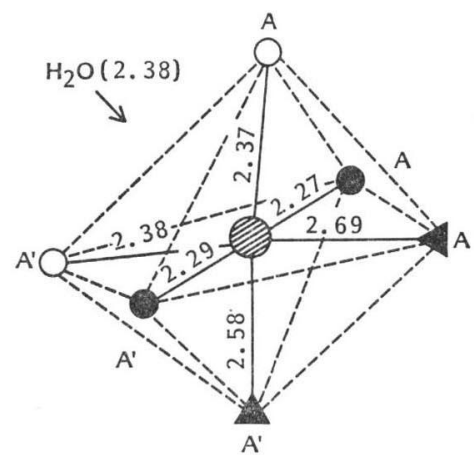

$\mathrm{Ca}^{++}$

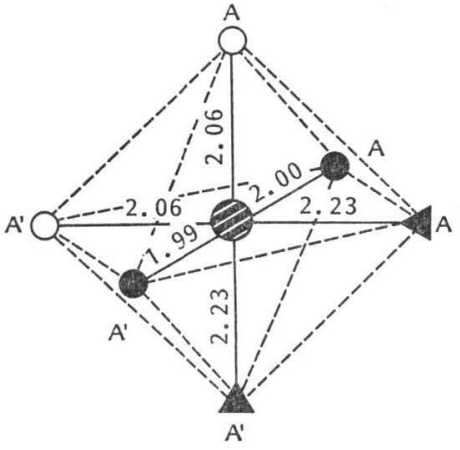

$\mathrm{Mg}^{++}$

Table 1. Analogs studied.

Numbering is that of calcimycin (1).

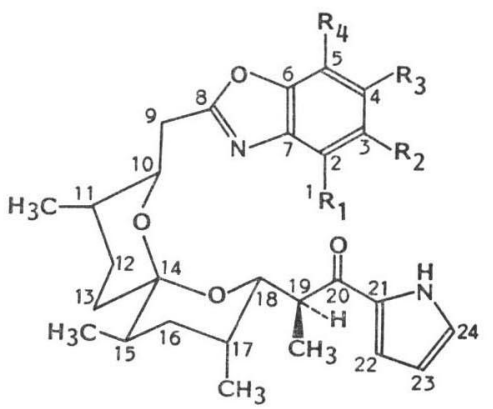

\begin{tabular}{cllll}
\hline Compounds & \multicolumn{1}{c}{$\mathrm{R}_{1}$} & \multicolumn{1}{c}{$\mathrm{R}_{2}$} & $\mathrm{R}_{3}$ & $\mathrm{R}_{4}$ \\
\hline $\mathbf{1}$ & $\mathrm{COOH}$ & $\mathrm{NHCH}_{3}$ & $\mathrm{H}$ & $\mathrm{H}$ \\
$\mathbf{2}$ & $\mathrm{H}$ & $\mathrm{COOH}$ & $\mathrm{H}$ & $\mathrm{H}$ \\
$\mathbf{3}$ & $\mathrm{COOH}$ & $\mathrm{H}$ & $\mathrm{H}$ & $\mathrm{H}$ \\
$\mathbf{4}$ & $\mathrm{COOH}$ & $\mathrm{H}$ & $\mathrm{H}$ & $\mathrm{CH}_{3}$ \\
$\mathbf{5}$ & $\mathrm{COOH}$ & $\mathrm{H}$ & $\mathrm{CH}$ & $\mathrm{H}$ \\
$\mathbf{6}$ & $\mathrm{COOH}$ & $\mathrm{CH}$ & $\mathrm{H}$ & $\mathrm{H}$ \\
$\mathbf{7}$ & $\mathrm{COOH}$ & $\mathrm{OH}$ & $\mathrm{H}$ & $\mathrm{H}$ \\
$\mathbf{8}$ & $\mathrm{COOH}$ & $\mathrm{N}\left(\mathrm{CH}_{3}\right)_{2}$ & $\mathrm{H}$ & $\mathrm{H}$ \\
$\mathbf{9}$ & $\mathrm{COOH}$ & $\mathrm{N}\left(\mathrm{CH}_{3}\right) \mathrm{C}_{2} \mathrm{H}_{5}$ & $\mathrm{H}$ & $\mathrm{H}$ \\
$\mathbf{1 0}$ & $\mathrm{COOH}$ & $\mathrm{N}\left(\mathrm{CH}_{3}\right) \mathrm{COCH}_{3}$ & $\mathrm{H}$ & $\mathrm{H}$ \\
$\mathbf{1 1}$ & $\mathrm{NOOH}$ & $\mathrm{N}\left(\mathrm{CH}_{3}\right) \mathrm{COCF}_{3}$ & $\mathrm{H}$ & $\mathrm{H}$ \\
\hline 12 & $\mathrm{OH}$ & $\mathrm{H}$ & \\
\hline
\end{tabular}

* X14885A: Backbone without 15-methyl.

discussed. Synthesis of $6\left(\mathrm{R}_{1}=\mathrm{COOH}, \mathrm{R}_{2}=\mathrm{CH}_{3}, \mathrm{R}_{3}=\mathrm{R}_{4}=\mathrm{H}\right)$ required the preparation of a 3-hydroxy-6-methyl anthranilate ester. We had failed previously to obtain this intermediate by rearrangement of the appropriate free hydroxylamine with $\mathrm{TsCl}-\mathrm{NEt}_{3}{ }^{9}$. . This synthesis was achieved via another route as shown in Scheme 2. 
Scheme 1.
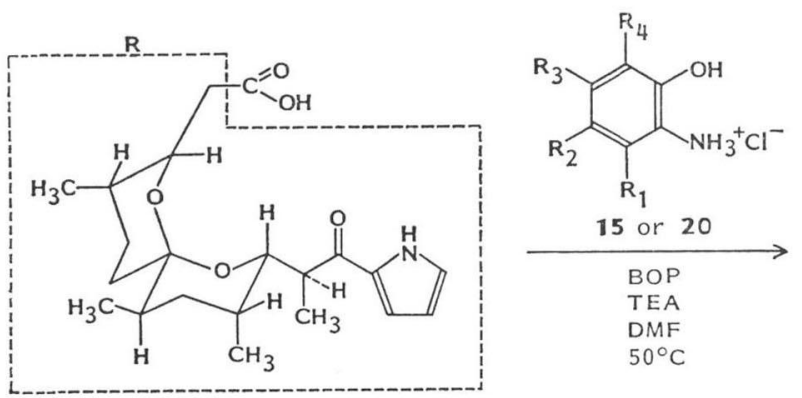<smiles>[R]C(=O)Nc1c([R])c([R])c([R3])c([R])c1[2H]</smiles>

22 or 24

21

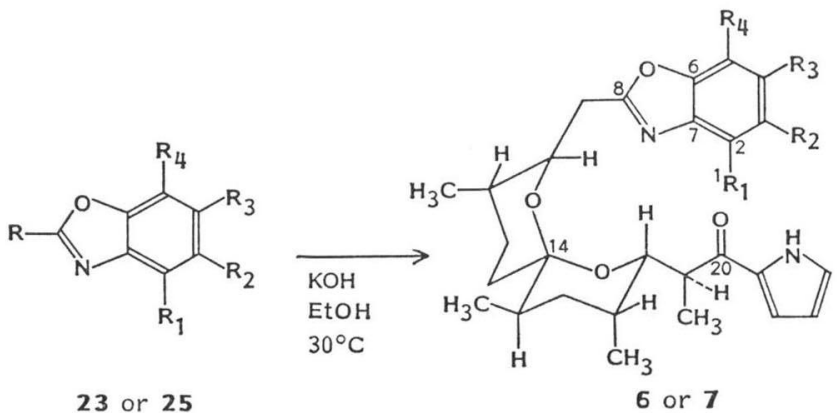

$$
\mathrm{R}_{3}=\mathrm{R}_{4}=\mathrm{H}
$$

15, 22, $23 \mathrm{R}_{1}=\mathrm{COOC}_{2} \mathrm{H}_{5}, \mathrm{R}_{2}=\mathrm{CH}_{3}$

20, 24, $25 \mathrm{R}_{1}=\mathrm{COOCH}_{3}, \mathrm{R}_{2}=\mathrm{OH}$

$6 \mathrm{R}_{1}=\mathrm{COOH}, \quad \mathrm{R}_{2}=\mathrm{CH}_{3}$

$7 \mathrm{R}_{1}=\mathrm{COOH}, \quad \mathrm{R}_{2}=\mathrm{OH}$

Scheme 2.

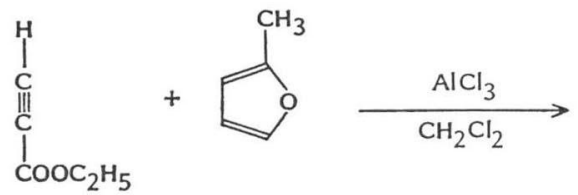<smiles>CCOC(=O)c1c(C)ccc(O)c1[N+](=O)[O-]</smiles>

14<smiles>CCOC(=O)c1cc(O)ccc1C</smiles><smiles>CCCCCCC(C)(C)[Mg]</smiles><smiles></smiles>

15

A Diels-Alder reaction between ethyl propiolate and 2-methylfuran led to the ester $13^{11)}$ which was separated from by-products by a sequence of selective extractions. This compound was nitrated to give 14 as the major product, the reduction of which, over Raney nickel, yielded $\mathbf{1 5 .}$

The structure of compound 7 is very close to that of X14885A (12), differing only by a methyl added in the 15-position on the spiroketal group. The preparation of the benzoxazole precursor 20 was carried out starting from gentisic acid (16) according to Scheme 3.

The two hydroxyanthranilates $\mathbf{1 5}$ and $\mathbf{2 0}$ were respectively coupled with the synthon $\mathbf{2 1}$ (Scheme 1) with the help of benzotriazolyl $N$-oxytrisdimethylaminophosphonium (BOP) reagent ${ }^{12)}$, cyclization 
Scheme 3.

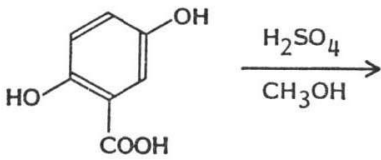

16<smiles>COC(=O)c1cc(O)ccc1O</smiles>

17

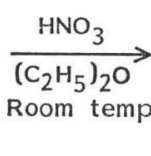<smiles>COC(=O)c1c(O)ccc(O)c1[N+](=O)[O-]</smiles>

18<smiles>CCOP=O</smiles><smiles>CC(=O)c1c(O)ccc(O)c1[N+]Cl</smiles>

20

to the oxazoles being accomplished with ethyl polyphosphate (EPP) ${ }^{13)}$. The hydrolysis of the ester group gave the calcimycin analogs 6 and 7.

In the case of the $p$-diphenol 20 , it was necessary to carry out coupling reaction under nitrogen to minimize air oxidation. However, the cyclization of the intermediate amide with EPP occurred rapidly.

Synthesis of Compounds $\mathbf{9 ,} \mathbf{1 0}$ and $\mathbf{1 1}$

$N$-Ethyl (9), $N$-acetyl (10) and $N$-trifluoroacetyl (11) calcimycins were obtained by conventional reactions performed on the natural metabolite, under the conditions described below.

We studied the conformation of the twelve calcimycin analogs by ${ }^{1} \mathrm{H}$ NMR at $400 \mathrm{MHz}$, in both chloroform and methanol. Careful examination of the coupling constants led us to the conclusion that all the compounds adopted almost identical conformations corresponding to a closed structure in chloroform with a head-to-tail chelation and a more open structure in methanol where the methylene benzoxazole arm is rotated. These results will be described in detail elsewhere.

\section{Calcium and Magnesium Carrier Properties}

It is evident from reviews dealing with this problem $^{14)}$, that there is no single test to characterize a carboxylic polyether ionophore. On the basis of both previous work done mainly by PfEIfFer and co-workers on calcimycin ${ }^{15)}$ and our own experimentation, we chose several complementary methods to obtain a characterization that was as complete as possible, purely physico-chemical measurements are described in this paper.

The commonly accepted overall transport process for calcimycin is a $\mathrm{M}^{++}-2 \mathrm{H}^{+}$antiport, represented in Fig. 2.

As we have shown in a model triphasic cell (water - chloroform - water) ${ }^{18)}$, the cation extraction is dependent on the acidic dissociation of the carrier and the heterogeneous formation constants of the monomeric and dimeric complexes at the interface. Further, during the release step we observed recently ${ }^{17)}$ that the kinetics are very different for calcium and magnesium, which may explain the much higher ionic flux for calcium in all membrane phases. These general considerations underly the choice of the physico-chemical methods used, the results of which are collected in Tables 2 and 3. 
Fig. 2. Calcimycin: a $\mathrm{M}^{++}$-carrier by an antiport $\mathrm{M}^{++}-2 \mathrm{H}^{+}$mechanism.

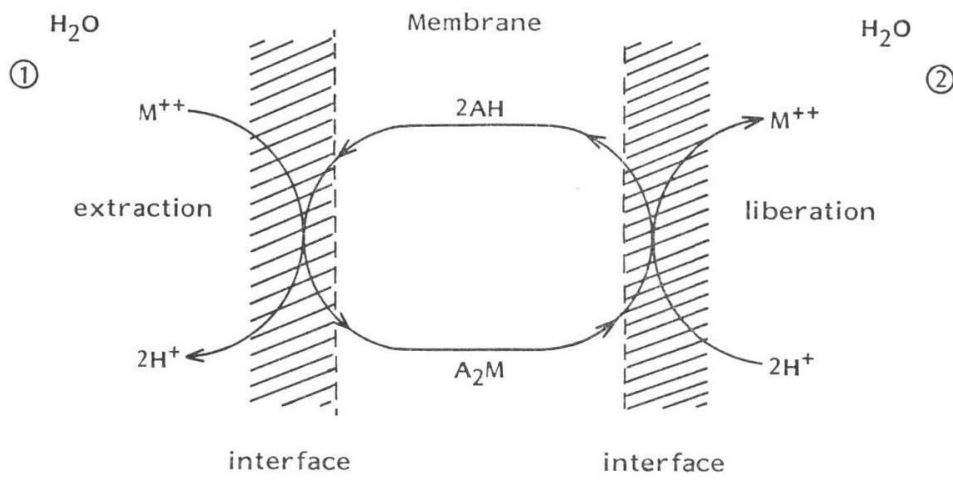

Table 2. Physico-chemical characterization of the analogs.

$p K a$, overall extraction constants $\beta_{1}$ and relative intrinsic extraction $\Delta \log \beta_{2}$ in a $\mathrm{H}_{2} \mathrm{O}$ - toluenebutanol $(70: 30)$ two-phase system.

\begin{tabular}{|c|c|c|c|c|c|}
\hline \multirow{2}{*}{ Compounds } & \multirow{2}{*}{$\left(\begin{array}{c}p K a \\
\mathrm{MeOH}-\mathrm{H}_{2} \mathrm{O} \\
70: 30\end{array}\right)$} & \multicolumn{2}{|c|}{$-\log \beta_{1}$} & \multicolumn{2}{|c|}{$\Delta \log \beta_{2}$} \\
\hline & & $\mathrm{Ca}^{++}$ & $\mathrm{Mg}^{++}$ & $\mathrm{Ca}^{++}$ & $\mathrm{Mg}^{++}$ \\
\hline 1 & 7.30 & 6.4 & 6.9 & 0 & 0 \\
\hline 2 & 6.34 & 13.3 & 12.7 & 8.8 & 7.7 \\
\hline 3 & 6.02 & 5.1 & 5.9 & 1.2 & 1.6 \\
\hline 4 & 6.53 & 6.9 & 6.9 & 2.0 & 1.5 \\
\hline 5 & 6.04 & 5.1 & 5.1 & 1.2 & 0.7 \\
\hline 6 & 5.19 & 7.7 & 8.1 & 4.5 & 5.4 \\
\hline 7 & 4.40 & 1.7 & 2.3 & 1.0 & 1.2 \\
\hline $\mathrm{X} 14885 \mathrm{~A}(\mathbf{1 2})$ & 4.48 & 1.7 & 2.3 & 0.9 & 1.1 \\
\hline 8 & 7.10 & 9.4 & 10.3 & 3.4 & 3.8 \\
\hline 9 & 7.10 & 10.3 & 11.3 & 4.3 & 4.8 \\
\hline 10 & 4.95 & 5.5 & 6.9 & 3.8 & 4.7 \\
\hline 11 & 4.87 & 5.3 & 6.3 & 3.7 & 4.2 \\
\hline
\end{tabular}

Acid Dissociation: The $p K a$ values given in Table 2 were measured by UV spectrophotometry according to KAUFFMAN et al. ${ }^{18)}$, in methanol - water, $70: 30(\mathrm{w} / \mathrm{w})$, which has been proposed as a possible model for the membrane-water interface for the study of carboxylic polyether dissociation ${ }^{19)}$. The values range over $2.9 \mathrm{pKa}$ units. Compounds 7 and $\mathbf{1 2}$ with an $\mathrm{OH}$ group in the 3 position are the most easily dissociated, as expected for a salicylic group, in contrast calcimycin (1) is the least acidic system. For other molecules, the acidity constants are the reflection of steric and electronic effects of substituents acting both on the acid and the anionic forms; this is especially the case when $R_{2}$ is a bulky substituent for $\mathbf{6}$ and 8 to $\mathbf{1 1}$.

Ionic Exchanges in a Two-phase Extraction System: This technique has been used for the characterization of ionophorous molecules giving neutral ${ }^{20)}$ or charged complexes ${ }^{21)}$; the organic phases have varied however. Calcimycin has been studied in detail using the water - toluene-butanol, 70: 30 system $^{222}$; accordingly we chose this system for the sake of consistency.

Typical extraction curves where the ratio $\left(\mathrm{M}^{++}\right) /($ionophore) in the organic phase is plotted versus the aqueous phase $\mathrm{pH}$ are shown in Fig. 3 for the naturally-occurring compounds $\mathbf{1}$ and $\mathbf{1 2}$ which are at the two extremes of the $p K a$ scala. As already pointed out ${ }^{13,22)}$, the extraction is clearly $\mathrm{pH}$-dependent which indicates a proton/metal-ion competition; the asymptote value near 0.5 corresponds to the 
Fig. 3. $\mathrm{Mg}^{++}$extraction curves for $\mathbf{1}$ and $\mathbf{1 2}$ in a biphasic system: $\mathrm{H}_{2} \mathrm{O}\left(\left(\mathrm{M}^{++}\right)=5 \times 10^{-2} \mathrm{M}\right.$, variable $\mathrm{pH}) /$ toluene - butanol, $70: 30$ ((ionophore) $=$ $\left.10^{-4} \mathrm{M}\right)$.

1; $p K a=7.30,12 ; p K a=4.48$.

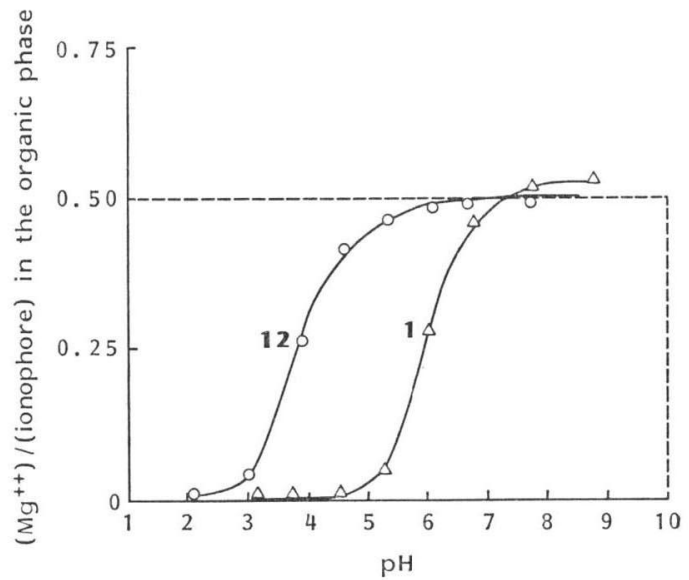

formation of a neutral dimeric complex. Results for calcimycin are in good agreement with previous ones ${ }^{22)}$.

All the twelve compounds studied gave the same kind of sigmoidal curves but distinctly shifted either towards the alkaline $\mathrm{pH}$ region for $2,6,8$ and 9 or towards the acid region for 7 , 10, 12. In this effect both the acid dissociation and the extracting capacity for each compound are involved. We have attempted to estimate the extent to which each of these factors is implicated.

The heterogeneous equilibrium, which can be studied experimentally, can be written.

$2 \mathrm{AH}_{\text {organic }}+\mathrm{M}^{++}{ }_{\mathrm{aq}} \rightleftharpoons \mathrm{A}_{2} \mathrm{M}_{\text {organic }}+2 \mathrm{H}^{+}{ }_{\text {aq }}$

where $\mathrm{AH}$ stands for the protonated form of the ionophore.

The corresponding $\beta_{1}$ constants, calculated at the point of half-saturation as previously proposed ${ }^{22)}$, are given in Table 2 for compounds $\mathbf{1} \sim \mathbf{1 2}$.

When, for instance, the naturally-occurring metabolites $\mathbf{1}$ and $\mathbf{1 2}$, are compared, there is a large difference in extracting capacity in favor of the latter, as shown by the $\beta_{1}$ values. This is at variance with the results obtained in methanol for the homogeneous equilibrium:

$$
2 \mathrm{~A}^{-}{ }_{\mathrm{NeOH}}+\mathrm{M}^{++}{ }_{\mathrm{MeOH}} \stackrel{\beta^{\prime}{ }_{2}}{\rightleftharpoons} \mathrm{A}_{2} \mathrm{M}_{\mathrm{MeOH}}
$$

where the respective $\log {\beta^{\prime}}_{2}$ values are: for $1, \mathrm{Ca}^{++} ; 16.2, \mathrm{Mg}^{++} ; 15.9^{23)}$ : for $12, \mathrm{Ca}^{++} ; 15.9, \mathrm{Mg}^{++}$; 14.9 (unpublished work), i.e. of the same order of magnitude and in fact higher for calcimycin. This discrepancy is due to the fact that the acid dissociation (3) is included in the overall equilibrium.

$$
\begin{aligned}
& \mathrm{AH}_{\text {organic }} \rightleftharpoons \mathrm{A}^{-} \text {interface } \\
& 2 \mathrm{~A}^{-} \mathrm{H}_{\text {interface }}^{+}+\mathrm{M}^{++}{ }_{\mathrm{aq}} \stackrel{\beta_{2}}{\rightleftharpoons} \mathrm{A}_{2} \mathrm{M}_{\text {organic }}
\end{aligned}
$$

As the $p K a$ at the interface is not known the $\beta_{2}$ value cannot be calculated. However, assuming that the differences between the $p K a$ given in Table 2 remain the same at the water - toluene-butanol interface, an increment value can be calculated.

$$
\Delta \log \beta_{2}=\Delta \log \beta_{1}+2 \Delta p K a_{\text {(methanol - water, 70:30) }}
$$

with respect to calcimycin (1), for instance. Results obtained in this way are given in Table 2 . They may reflect more accurately the intrinsic complexing properties of the molecules. All the differences are positive, and so $\mathbf{1}$ proves to be the best extracting system for calcium and magnesium but 12, 7 and then $\mathbf{5 , 3}$ and 4 are not far behind. Structures where $R_{2}$ is a bulky substituent, hindering the carboxylic group, and in which there is no longer any possibility of hydrogen bonding with this group, are poorer complexing systems, e.g. 6 (ortho- $\mathrm{CH}_{3}$ ) and 8 to 11 ( $N$-methyl substituted). Not unexpectedly when $\mathrm{R}_{1}=\mathrm{R}_{3}=\mathrm{R}_{4}=\mathrm{H}$ and $\mathrm{R}_{2}=\mathrm{COOH}$ the corresponding structure 2 loses all the calcimycin properties. The different situation with unfavorable steric arrangements are shown in Scheme 4. 
Scheme 4.<smiles></smiles><smiles></smiles><smiles></smiles>

$8 \sim 11$

Fig. 4. Release curves for $\mathbf{1}$ and $\mathbf{1 2 .}$

$\mathrm{pH}$ of the aqueous phases are mentioned on the curves.

$\mathrm{Ca}^{++}, \mathrm{Mg}^{++}$.
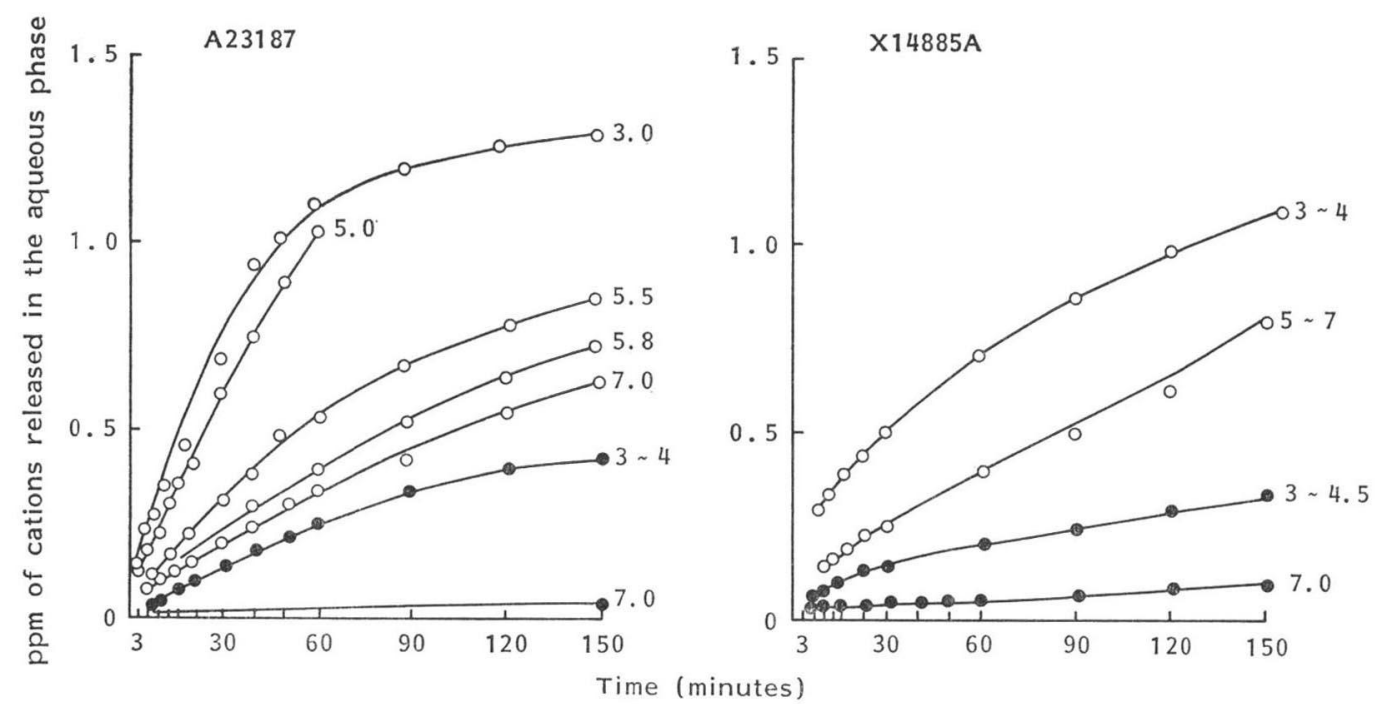

Table 3. Initial rates of decomplexation $\left(\mathrm{ppm} \times \mathrm{mn}^{-1} \times 10^{3}\right)$.

\begin{tabular}{|c|c|c|c|c|c|}
\hline \multirow{2}{*}{ Compounds } & \multicolumn{3}{|c|}{$\mathrm{Ca}^{++}$} & \multicolumn{2}{|c|}{$\mathrm{Mg}^{++}$} \\
\hline & pH 7 & $\mathrm{pH} 5$ & pH 3 & $\mathrm{pH} 7$ & $\mathrm{pH} 3$ or 4 \\
\hline 1 & 8.6 & 29 & 46 & 0.3 & 5 \\
\hline 3 & 85 & 85 & 183 & 5.3 & 18.3 \\
\hline $\mathrm{X} 14885 \mathrm{~A}(\mathbf{1 2})$ & 14 & 14 & 37 & 2.1 & 8 \\
\hline 8 & 95 & 10.3 & 15.3 & 28 & 46 \\
\hline 9 & 126 & 19 & 35 & 15 & 11 \\
\hline 10 & 116 & 116 & 116 & 28 & 17 \\
\hline 11 & 60 & 60 & 128 & 6 & 16 \\
\hline
\end{tabular}

The first conclusion emerging from these results is the prominent role of the 2-carboxyl benzoxazole sequence in the formation and stability of complexes.

No marked selectivity was evident between calcium and magnesium in the extraction experiments. For the reasons given above we made kinetic measurements for the decomplexation step, in the same two-phase system.

Decomplexation Kinetics in a Two Phase System: The study of the overall kinetics of cation release in a water - toluene-butanol (70:30) system was technically straightforward (see Experimental part), provided the $2: 1$ neutral complex initially introduced into the organic phase was carefully monitored. Typical release curves obtained for $\mathbf{1}$ and $\mathbf{1 2}$ are shown in Fig. 4, at different pH of the aqueous 
Scheme 5.<smiles>Cc1oc2ccc(O)c(C(=O)O)c2c1C</smiles><smiles></smiles>

phase. Initial rates of decomplexation in ppm $\times \mathrm{mn}^{-1} \times 10^{3}$ were calculated for compounds available in sufficient quantity. Results are collected in Table 3.

For all the compounds tested in this organic phase, the magnesium release is systematically

slower than that of calcium. Therefore, by analogy with calcimycin, a higher transmembrane flux for calcium is expected, although the extraction constants (which are the ratio of complexation rate to decomplexation rate) are of the same order of magnitude. This could be explained by the structural differences existing between $\mathrm{Ca}^{++}$and $\mathrm{Mg}^{++}$complexes and also by different kinetics of rehydration for the cations ${ }^{24}$.

The marked stability of associations with $\mathbf{1}$ and $\mathbf{1 2}$ is shown by the low initial rates measured. This can be ascribed to the hydrogen bonding network giving an organized structure, as shown in Scheme 5.

Further, for calcimycin, the initial rates of release were pH-dependent, due to the protonation of the secondary amine site over the acidic range.

Thus, these physico-chemical results obtained in an organic phase throw a new light on the complexation mechanism in the benzoxazole region and the $\mathrm{Ca}^{++} / \mathrm{Mg}^{++}$selectivity. But, this highly simplified model does not necessarily mimic biological membrane behavior. This comparison is undertaken in the following paper.

\section{Experimental}

NMR spectra were recorded on a Perkin-Elmer R24 ( ${ }^{1} \mathrm{H}$ NMR, $\left.60 \mathrm{MHz}\right)$ for routine studies or on Bruker spectrometers (WP 200 and WM 400) for high field spectra, with tetramethylsilane as internal standard. The resonance values are expressed in parts per million $(\delta)$. EI mass spectra were determined with either VG. 70-70 F or VG. $30 \mathrm{~F}$ spectrometer. The exact mass was measured when indispensable sample drying for $\mathrm{C}, \mathrm{H}, \mathrm{N}$ analysis was difficult to achieve (small amounts, decomposition ...). Optical rotations were measured with a Perkin Elmer model 141 polarimeter. Melting points were determined on a Reichert hot plate apparatus and are uncorrected TLC analysis was performed with Schleicher and Schüll plastic silica gel plates (F 1500/LS 254), home-made glass plates with Merck Kieselgel (60 PF 254-366) were used for the preparative scale. Column chromatography was carried out using Merck Kieselgel (60/70 230 mesh A STM). A23187 (calcimycin, 1) was from the stock sample of our laboratory, as was X14885A (12) isolated recently from the strain NRRL 12350. This novel ionophore was strictly identical (UV, IR, NMR, mass) to a sample kindly provided by Dr. J. W. WESTLEY.

\section{Synthesis}

\section{Ethyl 3-Hydroxy-2-nitro-6-methylbenzoate (14)}

Compound $\mathbf{1 3}^{11)}(3.8 \mathrm{~g})$ was stirred for 1 hour at $-20^{\circ} \mathrm{C}$ in an ether - fuming nitric acid solution (21 ml, $20: 1)$. The resulting mixture was separated on a column (silica gel, eluent; cyclohexane - EtOAc, 50: 50$)$. The first fraction eluted $(150 \mathrm{mg}$, yellow solid) was identified as a 4 - or 5-mononitrobenzoate and discarded: ${ }^{1} \mathrm{H}$ NMR $\left(60 \mathrm{MHz}, \mathrm{CDCl}_{3}\right) \delta \mathrm{ppm} / \mathrm{TMS} 1.35\left(3 \mathrm{H}, \mathrm{t}, \mathrm{COOCH}_{2} \mathrm{CH}_{3}\right), 2.2\left(3 \mathrm{H}, \mathrm{s}, \mathrm{Ar}-\mathrm{CH}_{3}\right)$, $4.3\left(2 \mathrm{H}, \mathrm{q}, \mathrm{COOCH} \mathrm{CH}_{3}\right), 7.8$ and $8.2(2 \mathrm{H}, 2 \times \mathrm{s}, \mathrm{Ar})$. The second fraction $(750 \mathrm{mg}$, yellow solid) was the 2-nitrobenzoate 14: MP 20 25 ${ }^{\circ} \mathrm{C}$; ${ }^{1} \mathrm{H}$ NMR $\left(60 \mathrm{MHz}, \mathrm{CDCl}_{3}\right) \delta \mathrm{ppm} / \mathrm{TMS} 1.3(3 \mathrm{H}, \mathrm{t}$, $\left.\mathrm{COOCH}_{2} \mathrm{CH}_{3}\right), 2.3\left(3 \mathrm{H}, \mathrm{s}, \mathrm{Ar}-\mathrm{CH}_{3}\right), 4.35\left(2 \mathrm{H}, \mathrm{q}, \mathrm{COOCH}_{2} \mathrm{CH}_{3}\right), 7.23(2 \mathrm{H}$, AB system, q, $J=8.5 \mathrm{~Hz}$, Ar). Third fraction ( $246 \mathrm{mg}$, yellow solid) was the 2,4- or 2,5-dinitrobenzoate: ${ }^{1} \mathrm{H}$ NMR $(60 \mathrm{MHz}$, 
$\left.\mathrm{CDCl}_{3}\right) \delta \mathrm{ppm} / \mathrm{TMS} 1.35\left(3 \mathrm{H}, \mathrm{t}, \mathrm{COOCH}_{2} \mathrm{CH}_{3}\right), 2.2\left(3 \mathrm{H}, \mathrm{s}, \mathrm{Ar}-\mathrm{CH}_{3}\right), 4.35\left(2 \mathrm{H}, \mathrm{q}, \mathrm{COOCH}_{2} \mathrm{CH}_{3}\right), 7.9$ $(1 \mathrm{H}, \mathrm{s}, \mathrm{Ar})$.

Ethyl 2-Amino-3-hydroxy-6-methylbenzoate Hydrochloride (15)

A mixture of $\mathbf{1 4}(750 \mathrm{mg}$ ), abs EtOH (35 ml), Raney Ni (equiv $1 \mathrm{~g})$, was shaken under hydrogen pressure $\left(700 \mathrm{~g} / \mathrm{cm}^{2}\right)$, at room temp for 2 hours. The catalyst was filtered off and the solvent removed. The residue was dissolved in dry ether and saturated with hydrogen chloride, to give 15 as a white solid (695 mg): ${ }^{1} \mathrm{H}$ NMR (60 MHz, DMSO) $\delta \mathrm{ppm} / \mathrm{TMS} 1.25\left(3 \mathrm{H}, \mathrm{t}, \mathrm{COOCH}_{2} \mathrm{CH}_{3}\right), 2.2\left(3 \mathrm{H}, \mathrm{s}, \mathrm{Ar}-\mathrm{CH}_{3}\right)$, $4.25\left(2 \mathrm{H}, \mathrm{q}, \mathrm{COOCH} \mathrm{CH}_{3}\right), 6 \sim 7\left(3 \mathrm{H}\right.$, br s, $\left.\mathrm{NH}_{3}{ }^{+}\right), 6.95(2 \mathrm{H}, \mathrm{AB}$ system, q, $J=8 \mathrm{~Hz}, \mathrm{Ar})$.

Methyl 2,5-Dihydroxybenzoate (17)

Commercial gentisic acid $(10 \mathrm{~g}), \mathrm{MeOH}(130 \mathrm{ml})$ and concd $\mathrm{H}_{2} \mathrm{SO}_{4}(2 \mathrm{ml})$ were heated under reflux for 12 hours. After concentration of the solution, the residue was diluted with $\mathrm{H}_{2} \mathrm{O}$, extracted with ether and purified by column chromatography (silica gel, eluent; cyclohexane - EtOAc, 80: 20) to give 17 (9.5 g): MP $86 \sim 87^{\circ} \mathrm{C}$. The structure was confirmed by ${ }^{1} \mathrm{H}$ NMR (60 $\mathrm{MHz}, \mathrm{CDCl}_{3}$ ).

Methyl 2,5-Dihydroxy-6-nitrobenzoate (18)

$17(4 \mathrm{~g})$ was treated with nitric acid as above for 14 at $0^{\circ} \mathrm{C}$. Two main products were separated by column chromatography (silica gel, eluent; cyclohexane - EtOAc, $80: 20)$ which were $19(0.7 \mathrm{~g})$ and $18(2.2 \mathrm{~g})$.

19 (yellow solid): ${ }^{1} \mathrm{H}$ NMR $\left(60 \mathrm{MHz}, \mathrm{CDCl}_{3}\right) \delta \mathrm{ppm} / \mathrm{TMS} 4.0\left(3 \mathrm{H}, \mathrm{s}, \mathrm{COOCH}_{3}\right), 7.7(2 \mathrm{H}, \mathrm{s}, \mathrm{Ar})$.

18 (Yellow solid): MP $117 \sim 118^{\circ} \mathrm{C} ;{ }^{1} \mathrm{H}$ NMR $\left(60 \mathrm{MHz},\left(\mathrm{CD}_{3}\right)_{2} \mathrm{CO}\right) \delta \mathrm{ppm} / \mathrm{TMS} 3.9(3 \mathrm{H}, \mathrm{s}$, $\left.\mathrm{COOCH}_{3}\right), 7.2(2 \mathrm{H}, \mathrm{AB}$ system, q, $J=9 \mathrm{~Hz}, \mathrm{Ar}), 8.5 \sim 9.5(2 \mathrm{H}$, br s, $\mathrm{Ar}-\mathrm{OH}) ; \mathrm{m} / z(\mathrm{M})$, found 213.0297, calcd 213.0271 for $\mathrm{C}_{8} \mathrm{H}_{7} \mathrm{NO}_{6}$.

Methyl 6-Amino-2,5-dihydroxybenzoate Hydrochloride (20)

A mixture of 18 (2.2 g), abs EtOH (50 ml) and $\mathrm{PtO}_{2}(220 \mathrm{mg})$ were shaken under hydrogen pressure $\left(700 \mathrm{~g} / \mathrm{cm}^{2}\right)$ for 4 hours. The same method of isolation as for $\mathbf{1 5}$ gave $20\left(1.3 \mathrm{~g}\right.$, white solid): ${ }^{1} \mathrm{H}$ NMR $(60 \mathrm{MHz}, \mathrm{DMSO}) \delta \mathrm{ppm} / \mathrm{TMS} 4.0\left(3 \mathrm{H}, \mathrm{s}, \mathrm{COOCH}_{3}\right), 5.0$ to $5.6\left(3 \mathrm{H}, \mathrm{br} \mathrm{s}, \mathrm{NH}_{3}{ }^{+}\right), 6.5(2 \mathrm{H}, \mathrm{AB}$ system, q, $J=8 \mathrm{~Hz}, \mathrm{Ar}), 8.8 \sim 9.3(2 \mathrm{H}$, br s, $\mathrm{Ar}-\mathrm{OH})$.

Ethyl 2- $N$-((3,9,11-Trimethyl-8-(1-methyl-2-oxo-2-(1H-pyrrol-2-yl)ethyl)-1,7-dioxaspiro-(5.5)undec-2-yl)acetyl)-3-hydroxy-6-methylanthranilate (22)

A light-protected solution of $\mathbf{1 5}(100 \mathrm{mg})$ in DMF $(20 \mathrm{ml})$, triethylamine (TEA, $170 \mathrm{mg})$, synthon $21(16 \mathrm{mg}$ ) and benzotriazol-1-yl-oxy-tris(dimethylamino)phosphonium or BOP (200 mg), were stirred in a water-bath at $50^{\circ} \mathrm{C}$ for 7 hours, poured into $\mathrm{H}_{2} \mathrm{O}$, extracted with ether, dried over $\mathrm{Na}_{2} \mathrm{SO}_{4}$ and purified by TLC (eluent; cyclohexane - EtOAc, 50: 50) to yield $22(150 \mathrm{mg})$ as a white foam. MP 59 $60^{\circ} \mathrm{C} ;[\alpha]_{578}^{25}+74^{\circ}\left(c 0.0015, \mathrm{CHCl}_{3}\right) ; \mathrm{m} / z(\mathrm{M})$, found 554.2976 , calcd 554.2981 for $\mathrm{C}_{31} \mathrm{H}_{42} \mathrm{~N}_{2} \mathrm{O}_{7} ;{ }^{1} \mathrm{H}$ $\operatorname{NMR}\left(200 \mathrm{MHz}, \mathrm{CDCl}_{3}\right) \delta \mathrm{ppm} / \mathrm{TMS} 1.40\left(3 \mathrm{H}, \mathrm{t}, \mathrm{COOCH}_{2} \mathrm{CH}_{3}\right), 2.35\left(3 \mathrm{H}, \mathrm{s}, \mathrm{Ar}-\mathrm{CH}_{3}\right), 2.4$ and 2.6 $\left(2 \mathrm{H}, \mathrm{q}, 9-\mathrm{H}_{\mathrm{A}}\right.$ and $\left.9-\mathrm{H}_{\mathrm{B}}\right), 4.1(1 \mathrm{H}, \mathrm{m}, 10-\mathrm{H}), 4.4\left(2 \mathrm{H}, \mathrm{q}, \mathrm{COOCH}_{2} \mathrm{CH}_{3}\right), 6.25(1 \mathrm{H}, \mathrm{m}, 23-\mathrm{H}), 6.95(1 \mathrm{H}$, br s, 22-H), $7.05(1 \mathrm{H}, \mathrm{s}, 24-\mathrm{H}), 7.07(2 \mathrm{H}$, br s, Ar), 8.25, 9.4 and $9.6(3 \mathrm{H}$, br s, pyrrole $\mathrm{NH}$, amide $\mathrm{NH}$ and $\mathrm{OH})$.

Ethyl 5-Methyl-2-((3,9,11-trimethyl-8-(1-methyl-2-oxo-2-(1H-pyrrol-2-yl)ethyl)-1,7-dioxaspiro(5.5)-undec-2-yl)methyl)-4-benzoxazolecarboxylate (23)

A light-protected solution of $22(56 \mathrm{mg})$, ethylpolyphosphate or EPP $(2 \mathrm{~g})$ in $\mathrm{CHCl}_{3}(8 \mathrm{ml})$, was stirred in a water-bath at $66^{\circ} \mathrm{C}$ for 1 hour, diluted with $\mathrm{H}_{2} \mathrm{O}$, extracted with ether, dried over $\mathrm{Na}_{2} \mathrm{SO}_{4}$ to yield $23(28 \mathrm{mg})$ as a white foam: MP $53 \sim 54^{\circ} \mathrm{C} ;[\alpha]_{578}^{25}+160^{\circ}\left(c 0.0024, \mathrm{CHCl}_{3}\right) ; \mathrm{m} / z(\mathrm{M})$, found 536.2914, calcd 536.2876 for $\mathrm{C}_{31} \mathrm{H}_{40} \mathrm{~N}_{2} \mathrm{O}_{6} ;{ }^{1} \mathrm{H}$ NMR (200 MHz, $\left.\mathrm{CDCl}_{3}\right) \delta \mathrm{ppm} / \mathrm{TMS} 1.4(3 \mathrm{H}, \mathrm{t}$, $\left.\mathrm{COOCH}_{2} \mathrm{CH}_{3}\right), 2.55\left(3 \mathrm{H}, \mathrm{s}, \mathrm{Ar}-\mathrm{CH}_{3}\right), 2.9$ and $3.1\left(2 \mathrm{H}, 2 \times \mathrm{q}, 9-\mathrm{H}_{\mathrm{A}}\right.$ and $\left.9-\mathrm{H}_{\mathrm{B}}\right), 4.05(1 \mathrm{H}, \mathrm{m}, 10-\mathrm{H}), 4.5$ $\left(2 \mathrm{H}, \mathrm{d} \mathrm{q}, \mathrm{COOCH}_{2} \mathrm{CH}_{3}\right), 6.25(1 \mathrm{H}, \mathrm{m}, 23-\mathrm{H}), 6.9(1 \mathrm{H}$, br s, 22-H), $7.05(1 \mathrm{H}$, br s, 24-H), 7.15 and 7.55 $(2 \mathrm{H}, 2 \times \mathrm{d}, \mathrm{Ar}), 10.0(1 \mathrm{H}$, br s, pyrrole $\mathrm{NH})$.

5-Methyl-2-((3,9,11-trimethyl-8-(1-methyl-2-oxo-2-(1H-pyrrol-2-yl)ethyl)-1,7-dioxaspiro-(5.5)undec-2-yl)methyl)-4-benzoxazolecarboxylic Acid (6)

A light-protected mixture of $\mathbf{2 3}(100 \mathrm{mg})$ in $\mathrm{EtOH}(100 \mathrm{ml})$ and $10 \%$ potassium hydroxide $(7 \mathrm{ml})$ 
was stirred at $30^{\circ} \mathrm{C}$ for 18 hours, poured into $\mathrm{H}_{2} \mathrm{O}(200 \mathrm{ml})$, adjusted to $\mathrm{pH} 4.5$ with $0.1 \mathrm{~N} \mathrm{HCl}$, extracted with ether and dried over $\mathrm{Na}_{2} \mathrm{SO}_{4}$. After ether evaporation, the residue was purified by TLC (eluent; cyclohexane - EtOAc, 50: 50). The product was then dissolved in an EtOH $-\mathrm{H}_{2} \mathrm{O}-\mathrm{Me}_{2} \mathrm{CO}$ solution and acidified with ethanolic $\mathrm{H}_{3} \mathrm{PO}_{4}(10 \%)$. The solvents were removed to yield $6(86 \mathrm{mg})$ as a white foam: MP $64 \sim 65^{\circ} \mathrm{C}$; $[\alpha]_{578}^{25}+77^{\circ}\left(c 0.0012, \mathrm{CHCl}_{3}\right) ; m / z(\mathrm{M})$, found 508.2550 , calcd 508.2572 for $\mathrm{C}_{29} \mathrm{H}_{30} \mathrm{~N}_{2} \mathrm{O}_{8} ;{ }^{1} \mathrm{H}$ NMR $\left(200 \mathrm{MHz}, \mathrm{CDCl}_{3}\right) \delta \mathrm{ppm} / \mathrm{TMS} 2.8\left(3 \mathrm{H}, \mathrm{s}, \mathrm{Ar}-\mathrm{CH}_{3}\right), 2.93$ and $3.1(2 \mathrm{H}, 2 \times \mathrm{q}$, $9-\mathrm{H}_{\mathrm{A}}$ and $\left.9-\mathrm{H}_{\mathrm{B}}\right), 4.3(1 \mathrm{H}, \mathrm{m}, 10-\mathrm{H}), 6.22(1 \mathrm{H}, \mathrm{m}, 23-\mathrm{H}), 6.92(1 \mathrm{H}$, br s, 22- $\mathrm{H}), 7.06(1 \mathrm{H}$, br s, 24-H), 7.29 and $7.67(2 \mathrm{H}, 2 \times \mathrm{d}, 4-\mathrm{H}$ and $5-\mathrm{H}), 9.80(1 \mathrm{H}$, br s, pyrrole $\mathrm{NH})$.

Methyl 2- $N$-((3,9,11-Trimethyl-8-(1-methyl-2-oxo-2-(1H-pyrrol-2-yl)ethyl)-1,7-dioxaspiro-(5.5)-undec-2-yl)acetyl)-3,6-dihydroxyanthranilate (24)

The method described for obtaining 22 from 15 was applied to $20(100 \mathrm{mg})$ with the synthon $\mathbf{2 1}$, but stirring at $50^{\circ} \mathrm{C}$ was maintained for 5 hours under nitrogen, giving after purification $24(29 \mathrm{mg})$ as a white foam: MP $67 \sim 68^{\circ} \mathrm{C}$. This compound was unstable and treated without further study.

Methyl 6-Hydroxy-2-((3,9,11-trimethyl-8-(1-methyl-2-oxo-2-(1H-pyrrol-2-yl)ethyl)-1,7-dioxaspiro(5.5)-undec-2-yl)methyl)-4-benzoxazolecarboxylate (25)

This compound was obtained from 24 in the same way as 23 , except that refluxing was carried out for 1 hour. White foam: MP $72 \sim 73^{\circ} \mathrm{C} ;[\alpha]_{578}^{25}+31^{\circ}\left(c 0.0107, \mathrm{CHCl}_{3}\right) ; \mathrm{m} / z(\mathrm{M})$, found 524.2522, calcd 524.2513 for $\mathrm{C}_{29} \mathrm{H}_{38} \mathrm{~N}_{2} \mathrm{O}_{7} ;{ }^{1} \mathrm{H}$ NMR $\left(400 \mathrm{MHz}, \mathrm{CDCl}_{3}\right) \delta \mathrm{ppm} / \mathrm{TMS} 2.9$ and $3.1(2 \mathrm{H}, 2 \times \mathrm{q}$, 9- $\mathrm{H}_{\mathrm{A}}$ and $\left.9-\mathrm{H}_{\mathrm{B}}\right), 4.1\left(3 \mathrm{H}, \mathrm{s}, \mathrm{COOCH}_{3}\right), 4.25(1 \mathrm{H}, \mathrm{m}, 10-\mathrm{H}), 6.20(1 \mathrm{H}$, br s, $23-\mathrm{H}), 6.90(1 \mathrm{H}, \mathrm{br}$ s, 22$\mathrm{H}), 6.95(1 \mathrm{H}$, br s, 24-H), 7.0 and $7.65(2 \mathrm{H}, 2 \times \mathrm{d}, \mathrm{Ar}), 10.15(1 \mathrm{H}$, br s, pyrrole NH$), 11.20(1 \mathrm{H}, \mathrm{s}, \mathrm{Ar}-$ $\mathrm{O} H)$.

6-Hydroxy-2-((3,9,11-trimethyl-8-(1-methyl-2-oxo-2-(1H-pyrrol-2-yl)ethyl)-1,7-dioxaspiro-(5.5)undec-2-yl)methyl)-4-benzoxazolecarboxylic Acid (7)

Hydrolysis of $\mathbf{2 5}(50 \mathrm{mg}$ ) was performed by the same method as $\mathbf{2 3}$ to give $\mathbf{7}(34 \mathrm{mg})$, white foam: MP 59 60 $0^{\circ}$; $[\alpha]_{578}^{25}+50^{\circ}\left(c 0.023, \mathrm{CHCl}_{3}\right) ; \mathrm{m} / z(\mathrm{M})$, found 510.2355 , calcd 510.2357 for $\mathrm{C}_{28} \mathrm{H}_{34} \mathrm{~N}_{2} \mathrm{O}_{7}$; ${ }^{1} \mathrm{H}$ NMR $\left(200 \mathrm{MHz}, \mathrm{CDCl}_{3}\right) \delta \mathrm{ppm} / \mathrm{TMS} 2.95$ and $3.11\left(2 \mathrm{H}, 2 \times \mathrm{q}, 9-\mathrm{H}_{\mathrm{A}}\right.$ and $\left.9-\mathrm{H}_{\mathrm{B}}\right), 4.26(1 \mathrm{H}, \mathrm{m}, 10-$ H), $6.26(1 \mathrm{H}, \mathrm{m}, 23-\mathrm{H}), 7.00(1 \mathrm{H}, \mathrm{d}, 4-\mathrm{H}), 6.92(1 \mathrm{H}$, br s, 22-H), $7.02(1 \mathrm{H}, \mathrm{br} \mathrm{s}, 24-\mathrm{H}), 7.69(1 \mathrm{H}, \mathrm{d}, 5-$ H), $9.50(1 \mathrm{H}$, br s, pyrrole NH), $10.95(1 \mathrm{H}$, br s, Ar-OH).

5-(Methylacetylamino)-2-((3,9,11-trimethyl-8-(1-methyl-2-oxo-2-(1H-pyrrol-2-yl)ethyl)-1,7-dioxaspiro-(5.5)-undec-2-yl)methyl)-4-benzoxazolecarboxylic Acid (10)

A23187 $(1 \mathrm{mM})$ was added with stirring in pyridinic solution at $0^{\circ} \mathrm{C}$ of acetic anhydride $(1 \mathrm{~mm})$. The temperature of the mixture was allowed to rise to $20^{\circ} \mathrm{C}$. After 3 hours, the pyridine was removed, the residue extracted with ether, washed with $0.1 \mathrm{~N} \mathrm{HCl}$. The organic layer was dried over $\mathrm{MgSO}_{4}$. After solvent removal, the compound was purified by TLC (eluent; EtOAc - MeOH, $80: 20$ ) and then acidified carefully with $0.1 \mathrm{~N} \mathrm{HCl}$. The yield for 10 was $94 \%$, white foam: MP $105 \sim 106^{\circ} \mathrm{C}$; $[\alpha]_{578}^{25}+5^{\circ}$ (c $\left.0.0025, \mathrm{CHCl}_{3}\right)$; MS m/z $565\left(\mathrm{M}^{+}\right)$, analysis correct for the hydrochloride $\mathrm{C}_{31} \mathrm{H}_{40} \mathrm{~N}_{3} \mathrm{O}_{7} \mathrm{Cl}(\mathrm{C}, \mathrm{H}, \mathrm{N})$; ${ }^{1} \mathrm{H}$ NMR $\left(200 \mathrm{MHz}, \mathrm{CDCl}_{3}\right) \delta \mathrm{ppm} / \mathrm{TMS} 1.78$ and $1.82\left(3 \mathrm{H}, \mathrm{d}^{*}, \mathrm{NCH}_{3} \mathrm{COCH}_{3}\right), 3.24$ and $3.27(3 \mathrm{H}$, d*, $\left.\mathrm{NCH}_{3}\right), 3.00$ and $3.14\left(2 \mathrm{H}, 2 \times \mathrm{d}, 9-\mathrm{H}_{\mathrm{A}}\right.$ and $\left.9-\mathrm{H}_{\mathrm{B}}\right), 4.18(1 \mathrm{H}, \mathrm{m}, 10-\mathrm{H}), 6.25(1 \mathrm{H}$, br s, 23-H), 6.93 $(1 \mathrm{H}$, br s, 22-H), $7.08(1 \mathrm{H}$, br s, 24-H), $7.30(1 \mathrm{H}, \mathrm{d}, 4-\mathrm{H}), 7.80(1 \mathrm{H}, \mathrm{d}, 5-\mathrm{H}), 10.0(1 \mathrm{H}$, br s, pyrrole $\mathrm{NH})$.

5-(Methyltrifluoroacetylamino)-2-((3,9,11-trimethyl-8-(1-methyl-2-oxo-2-(1 H-pyrrol-2-yl)ethyl)-1,7dioxaspiro-(5.5)-undec-2-yl)methyl)-4-benzoxazolecarboxylic Acid (11)

This compound was obtained from trifluoro acetic anhydride and $\mathrm{A} 23187$ by the method described previously. Yield $90 \%$, white foam: $\mathrm{MP} 86 \sim 87^{\circ} \mathrm{C} ;[\alpha]_{578}^{25}+16.6^{\circ}\left(c 0.0187, \mathrm{CHCl}_{3}\right) ; \mathrm{MS} \mathrm{m} / z 619\left(\mathrm{M}^{+}\right)$, Anal $\mathrm{C}_{31} \mathrm{H}_{38} \mathrm{~N}_{3} \mathrm{O}_{7} \mathrm{~F}_{3}(\mathrm{C}, \mathrm{H}, \mathrm{N}) ;{ }^{1} \mathrm{H}$ NMR $\left(200 \mathrm{MHz}, \mathrm{CDCl}_{3}\right) \delta \mathrm{ppm} / \mathrm{TMS} 3.32$ and $3.39\left(3 \mathrm{H}, \mathrm{d}, \mathrm{NCH}_{3}\right)$, 3.00 and $3.12\left(2 \mathrm{H}, 2 \times \mathrm{d}, 9-\mathrm{H}_{\mathrm{A}}\right.$ and $\left.9-\mathrm{H}_{\mathrm{B}}\right), 4.20(1 \mathrm{H}, \mathrm{m}, 10-\mathrm{H}), 6.22(1 \mathrm{H}, \mathrm{br} \mathrm{s}, 23-\mathrm{H}), 6.91(1 \mathrm{H}, \mathrm{br} \mathrm{s}$, 22-H), $7.04(1 \mathrm{H}$, br s, 24-H), $7.36(1 \mathrm{H}, \mathrm{d}, 4-\mathrm{H}), 7.80(1 \mathrm{H}, \mathrm{d}, 5-\mathrm{H}), 9.90(1 \mathrm{H}$, br s, pyrrole $\mathrm{NH})$.

* May exist as a mixture of two observable conformers with regard to the $\mathrm{N}\left(\mathrm{CH}_{3}\right) \mathrm{COCH}_{3}$ group. 
5-(Ethylmethylamino)-2-((3,9,11-trimethyl-8-(1-methyl-2-oxo-2-(1H-pyrrol-2-yl)ethyl)-1,7-dioxaspiro-(5.5)-undec-2-yl)methyl)-4-benzoxazolecarboxylic Acid (9)

To a solution of A23187 $(200 \mathrm{mg})$ in $\mathrm{MeOH}(50 \mathrm{ml})$ was added $\mathrm{KOH}(33 \mathrm{mg})$. Ethyliodide $(1$ $\mathrm{ml}$ ) was added dropwise to the stirred solution at $10^{\circ} \mathrm{C}$ and the mixture left overnight at room temp. After removal of the solvent, the residue was dissolved in $\mathrm{CHCl}_{3}$ and filtered. The evaporation of the solution yielded $9(120 \mathrm{mg})$, white foam: MP $95 \sim 96^{\circ} \mathrm{C} ;[\alpha]_{578}^{25}-68^{\circ}\left(\mathrm{c} 0.019, \mathrm{CHCl}_{3}\right) ; \mathrm{m} / z(\mathrm{M})$, found 551.2999, calcd 551.2985 for $\mathrm{C}_{31} \mathrm{H}_{41} \mathrm{~N}_{3} \mathrm{O}_{6} ;{ }^{1} \mathrm{H}$ NMR (200 MHz, $\mathrm{CDCl}_{3}$ ) $\delta \mathrm{ppm} / \mathrm{TMS} 1.11$ (3H, t, $\left.\mathrm{NCH}_{2} \mathrm{CH}_{3}\right), 3.17\left(2 \mathrm{H}, \mathrm{q}, \mathrm{NCH}_{2} \mathrm{CH}_{3}\right), 4.16(1 \mathrm{H}, \mathrm{m}, 10-\mathrm{H}), 6.24(1 \mathrm{H}, \mathrm{m}, 23-\mathrm{H}), 6.94(1 \mathrm{H}, \mathrm{m}, 22-\mathrm{H})$, $7.28\left(1 \mathrm{H}\right.$, br s, 24-H), $7.36(1 \mathrm{H}, \mathrm{d}, 4-\mathrm{H}), 7.75(1 \mathrm{H}, \mathrm{d}, 5-\mathrm{H}), 10.85(1 \mathrm{H}$, br s, pyrrole $\mathrm{NH}) .{ }^{13} \mathrm{C}$ NMR spectra (BBD and J-Mod) confirmed structures of compounds 6, 7, 9, 10, 11.

Calcium and Magnesium Two-phase Extractions

The experimental conditions were those of ref 22 .

Decomplexation Kinetics in the Two-phase System

The dimeric complex prepared by exact neutralization of $\mathrm{A} 23187$ by $\mathrm{Mg}(\mathrm{OH})_{2}$ or $\mathrm{Ca}(\mathrm{OH})_{2}$ was dissolved in the toluene - butanol $(70: 30)$ phase at the concentration $0.5 \times 10^{-4} \mathrm{M}$. Five $\mathrm{ml}$ of this solution were poured carefully into a cell containing $5 \mathrm{ml}$ of an aqueous buffered solution (tris- $\beta, \beta^{\prime}$ dimethylglutaric acid) of variable $\mathrm{pH}$. The two phases were stirred separately at $600 \mathrm{rot} / \mathrm{minute}$ without disturbing the interface. At regular periods, $1 \mathrm{ml}$ of the aqueous solution was taken up with a syringe and the $\mathrm{Ca}^{++}$and $\mathrm{Mg}^{++}$content measured by atomic absorption, $1 \mathrm{ml}$ of aqueous buffered solution was added to the cell to keep a constant aqueous volume.

\section{References}

1) Hamill, R. L.; M. Gorman, R. M. Gale, C. E. Higgens \& M. M. Hoehm: A23187 a new ionophore antibiotic for divalent cations. I. Discovery, isolation and properties. Abstracts 12th Intersci. Conf. Antimicrob. Agents Chemother., No. 65, Atlantic City, 1972

2) Westley, J. W. (Ed.): Notation and classification. In Polyether Antibiotics: Naturally Occuring Acid Ionophores. Vol. 1, Biology. Chap. 1, pp. 1 20, N. Dekker Inc., New York, 1982

3) Deber, C. M. \& D. R. Pfeiffer: Ionophore A23187. Solution conformations of the calcium complex and free acid deduced from proton and carbon-13 nuclear magnetic resonance studies. Biochemistry 15: $132 \sim 141,1976$

4) Pfeiffer, D. R.; R. W. TAYloR \& H. A. LARdy: Ionophore A-23187: Cation binding and transport properties. Ann. N.Y. Acad. Sci. 307: 402 423, 1978

5) TAnaka, C.; K. TAniyama \& M. Kusunoki: A phorbol ester and A-23187 act synergistically to release acetylcholine from the guinea pig ileum. FEBS Lett. 175: 165 169, 1984

6) Sмith, G. D. \& W. L. Duax: Crystal and molecular structure of the calcium ion complex of A23187. J. Am. Chem. Soc. 98: 1578 1580, 1976

7) Alleaume, M. \& Y. Barrans: Structure cristalline du complexe de magnesium de la calcimycine (A-23187). Can. J. Chem. 63: 3482 3485, 1985

8) Prudhomme, M. \& G. Jeminet: Semi-synthesis of A-23187 (calcimycin) analogs. Experientia 39: 256 258,1983

9) Prudhomme, M.; G. Dauphin, J. Guyot \& G. Jeminet: Semisynthesis of A23187 (calcimycin) analogs. II. Introduction of a methyl group on the benzoxazole ring. J. Antibiotics 37: 627 634, 1984

10) Westley, J. W.; C.-M. Liu, J. F. Blount, L. H. Sello, N. Troupe \& P. A. Miller: Isolation an characterization of a novel polyether antibiotic of the pyrrolether class, antibiotic X-14885A. J. Antibiotics 36: $1275 \sim 1278,1983$

11) Mc Culloch, A. W. \& A. G. Mc Innes: Influence of Lewis acids on the Diels-Alder reaction. IV. Reaction of 2-methyl and 2-phenyl furan with ethyl propiolate. Can. J. Chem. 49: 3152 3157, 1971

12) Castro, B.; J. R. Dormoy, G. Evin \& C. Selve: Reactifs de couplage peptidique IV(1)-L'hexafluorophosphate de benzotriazolyl N-oxytrisdimethylamino phosphonium (B.O.P.). Tetrahedron Lett. 1975: $1219 \sim 1222,1975$

13) Kanaoka, Y.; T. Hamada \& O. Yonemitsu: Polyphosphate ester as a synthetic agent. XIII. Syntheses of 2-substituted benzoxazoles and benzothiazoles with P.P.E. Chem. Pharm. Bull. 18: 587 590, 1970

14) Taylor, R. W.; R. F. Kauffman \& D. R. Pfeiffer: Cation complexation and transport by carboxylic 
acid ionophores. In Polyether Antibiotics: Naturally Occurring acid Ionophores. Vol. 1: Biology. Ed., J. W. Westley, pp. 103 184, N. Dekker Inc., New York, 1982

15) Debono, M.; R. M. Molloy, D. E. Dorman, J. W. Paschal, D. F. Babcock, C. M. Deber \& D. R. PfEIfFER: Synthesis and characterization of halogenated derivatives of the ionophore A23187: Enhanced calcium ion transport specificity by the 4-bromo derivative. Biochemistry 20: 6865 6872, 1981

16) Bolte, J.; C. Demuynck, G. Jeminet, J. Juillard \& C. Tissier: Etude comparée de trois antibiotiques ionophores: X-537A (lasalocide), A-23187 (calcimycine) et X-14547A. Complexation des cations I A et II A, transport de $\mathrm{Ca}^{++}$. Can. J. Chem. 60: 981 989, 1982

17) Bolte, J.; C. Demuynck \& G. Jeminet: Sélectivité du transport de $\mathrm{Ca}^{++} / \mathrm{Mg}^{++}$à travers une membrane liquide par A.23187 (calcimycine) et son dérivé $N$-méthyle. Can. J. Chem. 63: 3478 3481, 1985

18) Kauffman, R. F.; R. W. Taylor \& D. R. Pfeiffer: Acid-base properties of ionophore A23187 in methanol-water solutions and bound to unilamellar vesicles of dimyristoylphosphatidylcholine. Biochemistry 21: $2426 \sim 2435,1982$

19) Krause, G.; E. Grell, A. M. Albrecht-Gary, D. W. Boyd \& J. P. Schwing: Dynamic aspects of complex formation and dissociation between the antibiotic A-23187 and alkaline earth cations. Studies in physical and theoretical chemistry No. 24. In Physical Chemistry of Transmembrane Ion Motions. Ed., G. SpaCh, pp. 255 263, Elsevier, Amsterdam, 1983

20) Pressman, B. C.: Properties of ionophores with broad range cation selectivity. Fed. Proc. 32: 1698 1703,1973

21) Eisenman, G.; S. Ciani \& G. Szabo: The effects of the macrotetralide actin antibiotics on the equilibrium extraction of alkali metal salts into organic solvents. J. Membr. Biol. 1: 294 345, 1969

22) Pfeiffer, D. R. \& H. A. LARdy: Ionophore A23187: The effect of $\mathrm{H}^{+}$concentration on complex formation with divalent and monovalent cations and the demonstration of $\mathrm{K}^{+}$transport in mitochondria mediated by A23187. Biochemistry 15: 935 943, 1976

23) Tissier, C.; J. Juillard, M. Dupin \& G. Jeminet： Mode d'action de la calcimycine (A-23187). I. Equilibre avec les ions alcalins et alcalinoterreux en milieu homogène. J. Chim. Phys. 76: 611 617, 1979

24) Williams, R. J. P.: The symbiosis of metal and protein functions. Eur. J. Biochem. 150: 231 248, 1985 